\title{
TWO LAND SNAIL SPECIES OF THE MEKONG DELTA LIMESTONE HILLS (CAMBODIA, VIETNAM): AULACOSPIRA FURTIVA (EUPULMONATA: VERTIGINIDAE) AND GEORISSA CARINATA (NERITIMORPHA: HYDROCENIDAE)
}

\author{
JAAP J. VERMEULEN ${ }^{1 *}$, SIMON AIKEN ${ }^{2}$
}

${ }^{1} \mathrm{JK}$ art and science, Lauwerbes 82318 AT Leiden, Netherlands (e-mail: jk.artandscience@gmail.com)

${ }^{2} 1$ Hesketh Bank, York YO10 5HH, United Kingdom (e-mail: simonaiken@btinternet.com)

*corresponding author

ABSTRACT: We describe Aulacospira furtiva sp. n. (Pulmonata: Vertiginidae), and we expand on the protologue of Georissa carinata Sutcharit et Jirapatrasilp, 2020 (Neritomorpha: Hydrocenidae). Both species occur on limestone hills on the west flank of the Mekong delta, in Vietnam and Cambodia, and presumably are endemic to these hills.

KEY WORDS: land snails; Aulacospira; Georissa; Cambodia; Vietnam; Mekong Delta limestone hills

\section{INTRODUCTION}

The Mekong Delta Limestones (MDL) are a string of limestone hills in Vietnam and Cambodia, on the west flank of the Mekong river delta (see VERMEULEN et al. 2019a). The hills are hundreds of kilometres distant from other limestone hills, which has led to high levels of endemism (VERMEULEN et

\section{MATERIAL AND METHODS}

The descriptions and images are based on cleaned and air-dried shells. The field photographs were taken with a Sigma $105 \mathrm{~mm}$ macro lens mounted on a Nikon D3200 camera, with Nikon R1C1 lighting system. The collected specimens of Aulacospira furtiva were photographed with the same camera mounted on a trinocular microscope, using Helicon stacking software. The SEM images were taken with a Scanning Electron Microscope LEO 1450 VP at the Microscopic Center, Faculty of Science, Burapha University, Thailand.

The material studied derives from the private collections of the authors ('V' for coll. Vermeulen, 'A' al. 2007, 2019a, b). In this paper we present two species. The first, Aulacospira furtiva sp. n., is presumably a site endemic species. The other, Georissa carinata Sutcharit et Jirapatrasilp, 2020, occurs widely in the MDL but so far has not been reported elsewhere.

for coll. Aiken in the lists of examined material, below). Type specimens are stored in NHMUK (Natural History Museum of the United Kingdom, London). We also cite material from CUMZ (Chulalongkorn University Museum of Zoology, Bangkok, Thailand). Duplicate sets of the cited material will be stored in institutes in Vietnam and Cambodia.

The toponymy of the area is still unsettled. We have used names of hills as in VERMEULEN et al. (2019a: table 1). In that publication, coordinates are given for each hill. 


\section{TAXONOMY}

\section{Family Vertiginidae Fitzinger, 1833}

\section{Aulacospira furtiva sp. $\mathrm{n}$.}

Figs 1-7

Examined material. Cambodia: Kampot Province, Kampong Trach area: Phnom Kampong Trach (leg. S. AIKEN).

Holotype. NHMUK 20191332.

Paratypes. A/18 shells, V17990/1.
Cross diagnosis. Differs from A. conica Vermeulen, Phung et Truong, 2007 (also from the MDL) by the presence of apertural teeth. Recently, several species of Aulacospira have been described from continental Asia with more than two apertural teeth. Most similar to A. furtiva is A. panhai Dumrongrojwattana, 2008 (east Thailand), but this species has a more depressed spire. Aulacospira lampangensis Panha et Burch, 2002 (southeast Thailand) also has a more depressed spire, as well as a distinctly shouldered body whorl;

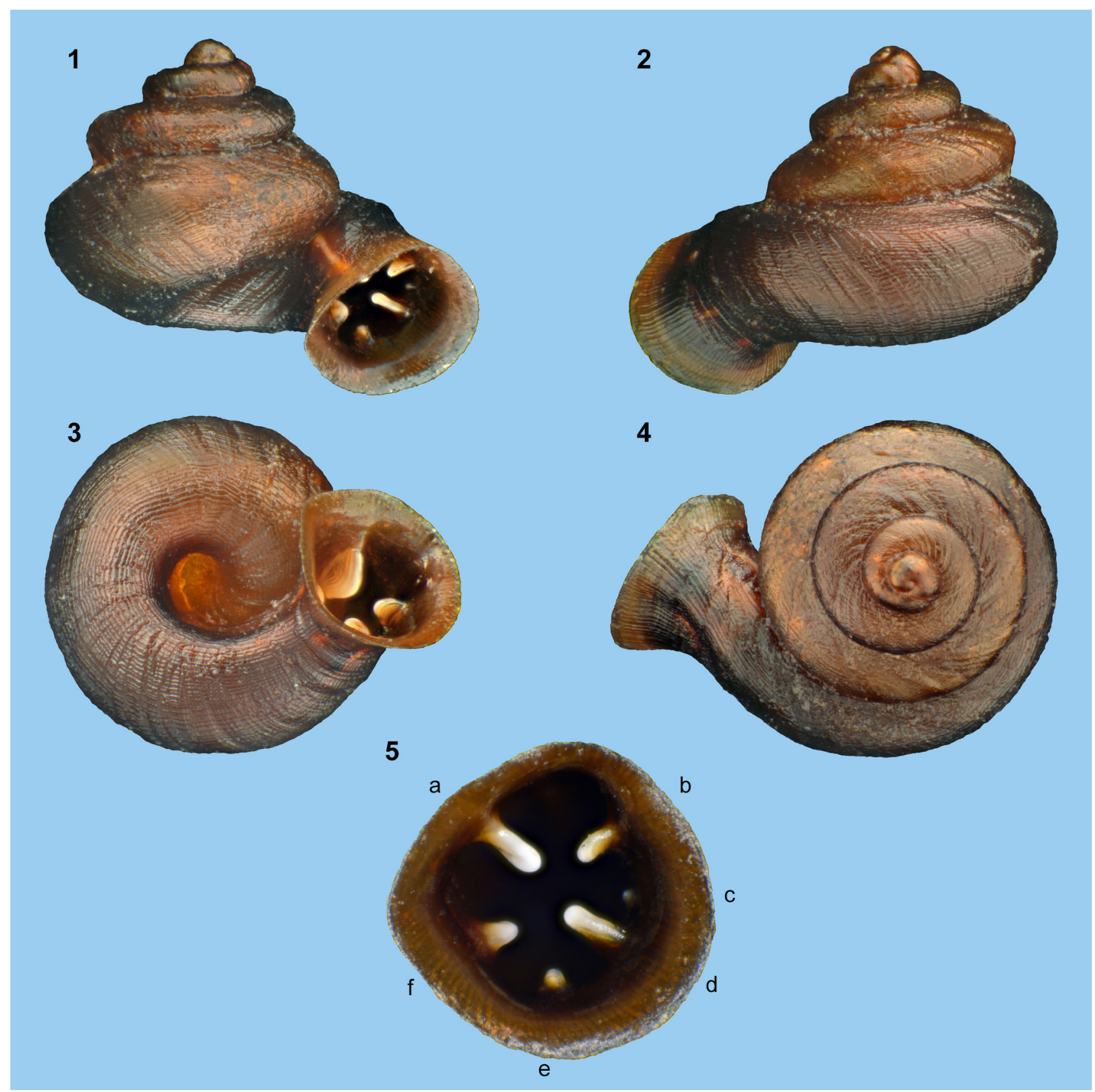

Figs 1-5. Aulacospira furtiva sp. n., paratype: 1 - frontal view, shell height $3.6 \mathrm{~mm}, 2$ - back view, 3 - umbilical view, 4 - apical view, 5 - apertural view (a - parietalis, $\mathrm{b}$ - suprapalatalis, $\mathrm{c}$ - palatalis, $\mathrm{d}$ - infrapalatalis, $\mathrm{e}$ - basalis, $\mathrm{f}$ - columellaris) (Photos: S. AIKEN) 
A. pluangtong Panha et Burch in PANHA et al. 2004 (southeast Thailand) has a more elevated spire and only 4 apertural teeth; $A$. smaesarnensis Panha et Burch, 2002 (north Thailand) has a distinctly more angular body whorl and has only 3 small apertural teeth. Philippine species of Aulacospira all have a shell with a conspicuously lower spire (see PÁLL-GERGELY et al. 2019 for an overview). The same source also illustrates Pseudostreptaxis azpeitiae (Hidalgo, 1890 [1890-1891]), which is somewhat similar to A. furtiva but differs by the obtusely keeled penultimate whorl, as well as the attached last portion of the body whorl.

Description. S h e 11 (Figs 1-5) very small, thin, opaque, dark red-brown. Spire somewhat depressed-conical with flat or slightly convex sides; apex not protruding, rounded. Surface slightly shiny. Whorls convex; protoconch and first teleoconch whorl rounded; other whorls obtusely angular at the periphery but shouldered close to the aperture and approx. flat above the periphery, body whorl slightly rounded below, edge of umbilical impression obtusely angular, surface inside shallowly furrowed; last part of the body whorl detached. Suture deeply impressed.

$\mathrm{S} \mathrm{c} \mathrm{u} \mathrm{l} \mathrm{p} \mathrm{t} \mathrm{u} \mathrm{r} \mathrm{e.} \mathrm{Protoconch} \mathrm{with} \mathrm{very} \mathrm{fine,} \mathrm{in-}$ conspicuous, well-spaced spiral threads. Teleoconch with unevenly spaced, somewhat raised growth lines, some developing into inconspicuous, low, obtuse riblets. Spiral sculpture: very fine, rather densely and somewhat unevenly spaced, thin, somewhat flattened threads.

A p e r t u r e (Fig. 5) free, with the parietal edge distant from the previous whorl, slightly tilted downwards with regard to the coiling axis, approx. circular to obtusely rectangular; free portion of the spire slightly narrowed towards the aperture, then expanding; teeth 5-6, all short and starting rather close to the peristome: one distinct, high, parietal lamella with an obtusely deltoid profile (marked 'a' in Fig. 5), one distinctly smaller and more rounded suprapalatalis ('b'), one infrapalatalis slightly larger than the suprapalatalis ('d'), with or without one tiny, knobshaped tooth in between these palatales (' $c$ '), one minute, short basalis ('e'), one almost knob-shaped columellaris (' $\mathrm{f}$ '). Peristome gradually spreading, thin.

U m b i 1 i c u s (Fig. 3) open, wide, with less than two whorls visible inside.

$\mathrm{D}$ i m e $\mathrm{n} \mathrm{s}$ i o $\mathrm{n} \mathrm{s}$. Height of shell 2.4-3.1 mm; width 3.2-3.6 mm; height/width 0.69-0.91; umbilicus $0.9-1.0 \mathrm{~mm}$ wide, which is $28-29 \%$ of the shell width; number of whorls 4-4 1/4; aperture height 1.2-1.4 mm; aperture width $1.5-1.6 \mathrm{~mm}$.

Habitat (Figs 6-7). Living on limestone rock inside a cave (twilight zone).

Distribution. Cambodia, Kampot Province, Kampong Trach area, Phnom Kampong Trach. Presumably a site endemic species. So far known from a single well-drained cave $22-25 \mathrm{~m}$ above the level of the surrounding plain.

Etymology. Furtivus (Latin) - stealthy, hidden, referring to the cave where the species was found.

\section{Family Hydrocenidae Troschel, 1857}

\section{Georissa carinata Sutcharit et Jirapatrasilp, 2020}

Figs 8-16

Holotype. CUMZ-CM094 (SUTCHARIT et al. 2020).
Examined material. Cambodia: Kampot Province, Kampot area: Phnom Chhngauk (leg. J. J. VeRMEULEN \& K. ANKER, V15530/>10 shells); Phnom Kbal Romeas (leg. J. J. VermeUlen \& K. ANKER, V15531/>10); Phnom La'Ang, cave at north end, with shrine at the entrance (leg. IUCN survey team, V16940/>10, V16941/>10, V17715/>10,
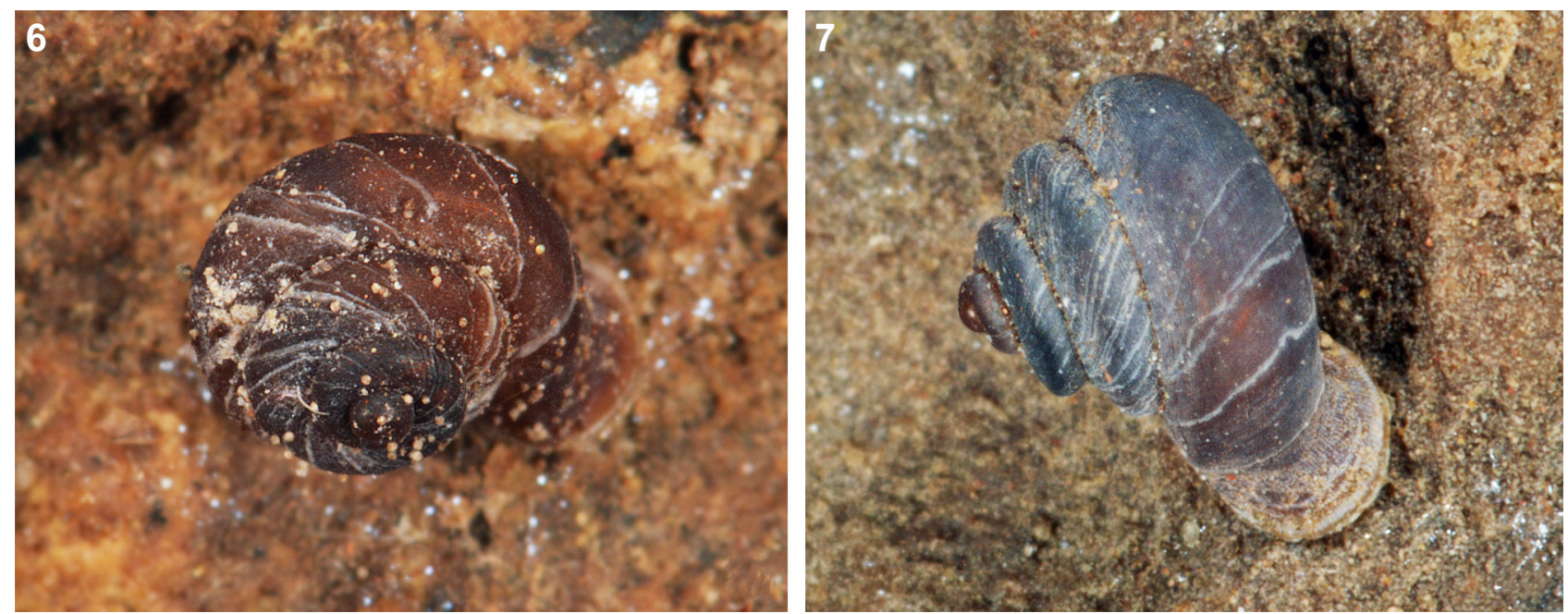

Figs 6-7. Living Aulacospira furtiva sp. n. on boulder in high-level cave, Phnom Kampong Trach (Photos: S. AIKEN) 

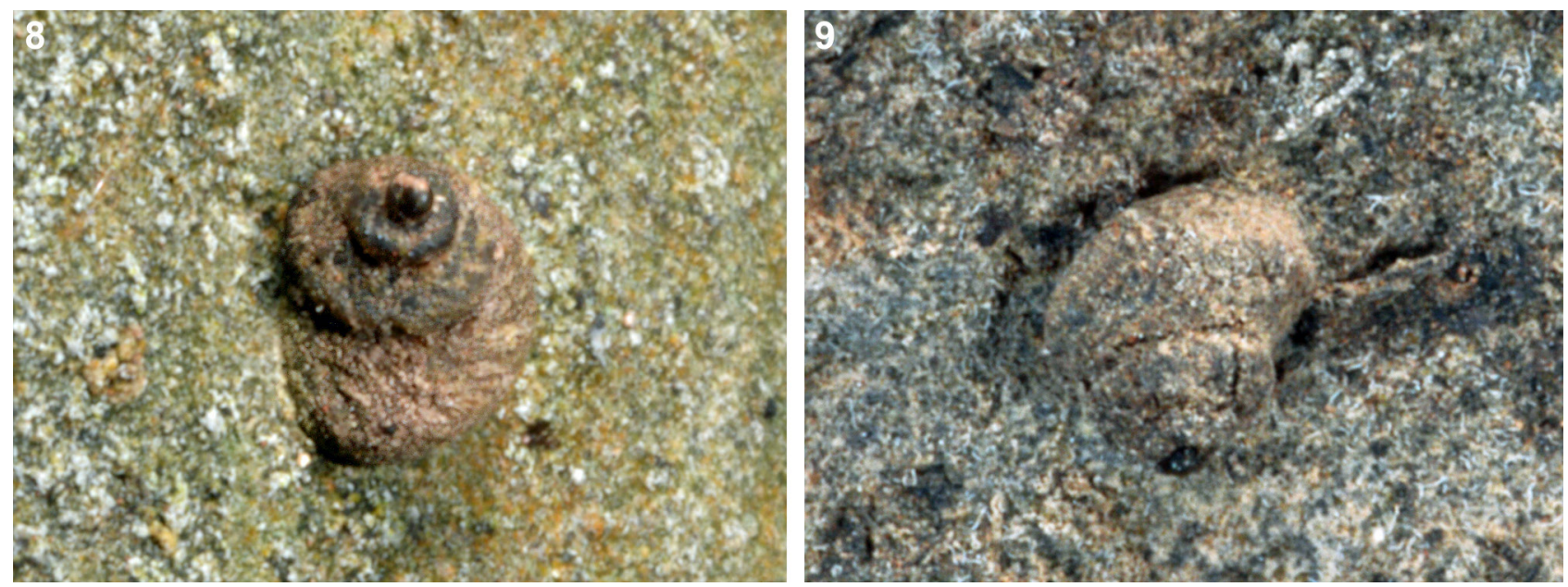

Figs 8-9. Living Georissa carinata Sutcharit et Jirapatrasilp, 2020 on limestone wall, Phnom Kampong Trach (Photos: S. AIKEN)

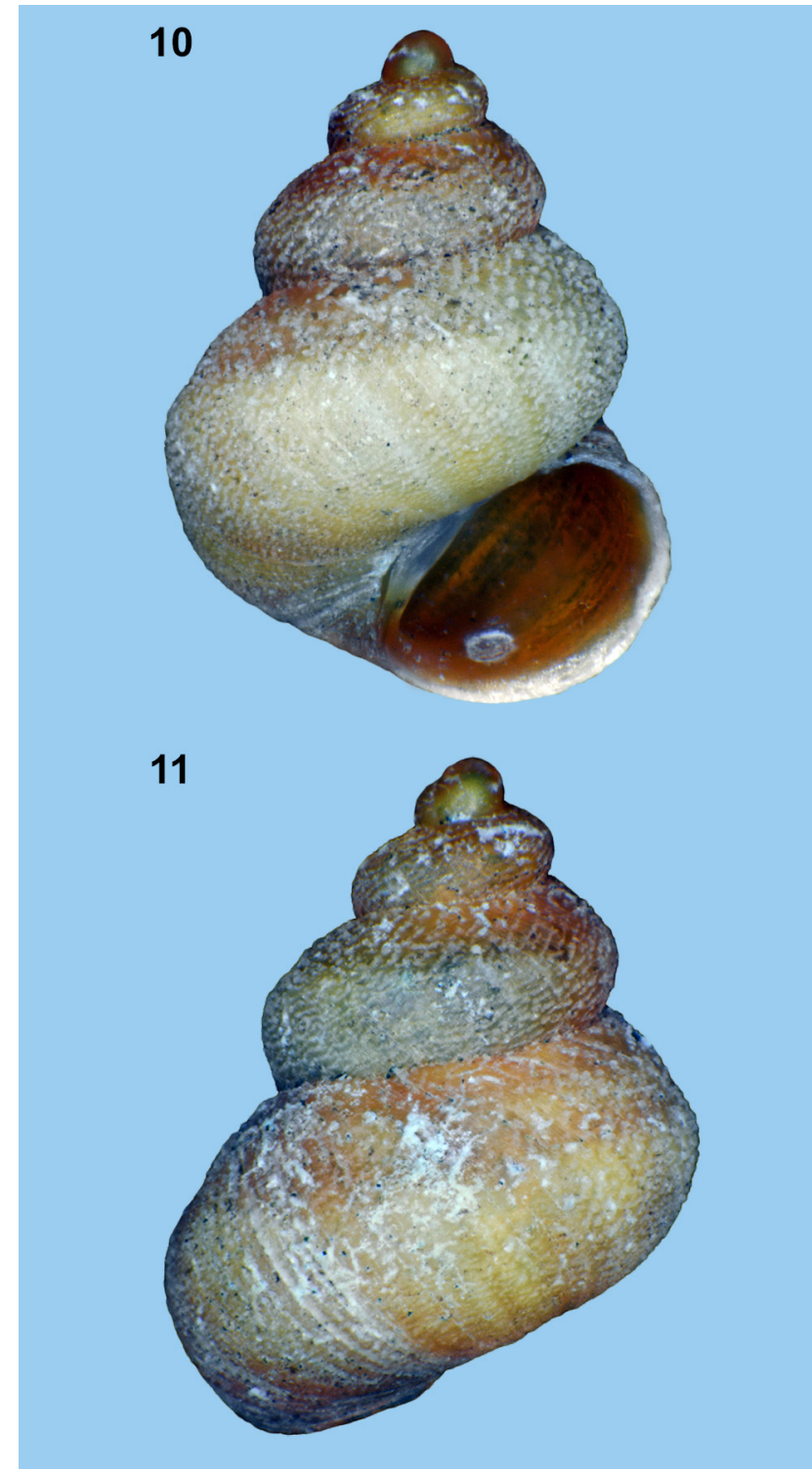

Figs 10-11. Georissa carinata Sutcharit et Jirapatrasilp, 2020: 10 - frontal view, shell height $3.5 \mathrm{~mm}, 11$ - back view (Photos: S. AIKEN)
V17716/>10, V17719/>10); ditto, limestone-enclosed valley at southwest-end (leg. IUCN survey team, 16939/>10); ditto, northernmost satellite limestone outcrop along east side of hill (leg. IUCN survey team, V16942/>10); ditto, northwest side, along path up to ridge to doline (leg. IUCN survey team, V17717/>10); ditto, northwest side, south-facing slope of doline (leg. IUCN survey team, V17718/> 10); ditto, southeast end (leg. IUCN survey team, V16938/>10); ditto, small satellite hill northwest of main hill (leg. J. J. VERMEULEN \& K. ANKER, V15529/> 10); Phnom Sor Sear (leg. J. J. VERMEULEN \& K. ANKER, V15532/>10). Kampong Trach area: Phnom Damrey, south hill (leg. J. J. VERMEULEN \& K. ANKER, V15527/>10); Phnom Kampong Trach (leg. J. J. Vermeulen \& K. ANKer, V15528/>10, leg. S. AIKEN, A); Banteay Meas area: nameless small limestone hill in CMIC-concession (leg. J. J. VERMEULEN \& K. ANKER, V15526/>10); Phnom Chruoh Chek (leg. J. J. Vermeulen \& K. ANKER, V15523/>10); Phnom Koun Sat (leg. J. J. VERMEULEN \& K. ANKER, V15524/>10); Phnom Kunea Luong, east hill (leg. J. J. Vermeulen \& K. ANKeR, V15525/>10); Phnom Teuk Srok, north hill (leg. J. J. VERMEULEN \& K. ANKER, V15522/>10); Phnom Toch (leg. J. J. VERMEULEN \& K. ANKer, V15520/>10); Phnom Totung (leg. J. J. VERMEULEN \& K. ANKER, V15521/>10). Vietnam: Kiên Giang Province, Hà Tiên area: Núi Đá Dựng, near Hà Tiên (leg. PHUNG LE CANG, V11437/>10); Núi Thạch Động, near Hà Tiên (leg. PHUNG LE CANG, V11469/> 10); Kiên Lương area: Núi Châu Hàng (leg. J. J. VERMEULEN \& K. ANKER, V14951/> 10); Núi Nai (leg. J. J. Vermeulen \& K. ANKER, V14837/>10); Núi Ông (leg. J. J. VERMEUlen \& K. ANKER, V14796/>10); Núi Trâu, north end, remnant of hill after quarrying (leg. J. J. VERMEULEN \& LY NGOC SAM, V14857/> 10); Bình An area: Hàng Cây Ớt (leg. J. J. VERMEULEN \& LY NGỌC SAM, V14805/> 10); Hòn Đá Lửa, east group, the middle (largest) island, west side 
(leg. J. J. VERMEULEN \& LY NGOC SAM; re-sampled by J. J. VERMEULEN \& K. ANKER, V14716/>10); Hòn Lô Cốc (leg. J. J. VeRMEULEN \& LY NGỌC SAM; re-sampled by J. J. VerMEULEN \& K. ANKER, V14732/>10); Núi Bà Tài (leg. J. J. Vermeulen, V11505/>10, leg. L. DeHARVEnG \& A. BeDOS; re-sampled J. J. VERMEULEN \& K. ANKER, V9980/>10, leg. TRUONG QUANG TAM \& PHUNG LE CANG; re-sampled by J. J. Vermeulen \& K. ANKer, V9962/>10); ditto, east flank (leg. L. DEHARVENG; re-sampled J.

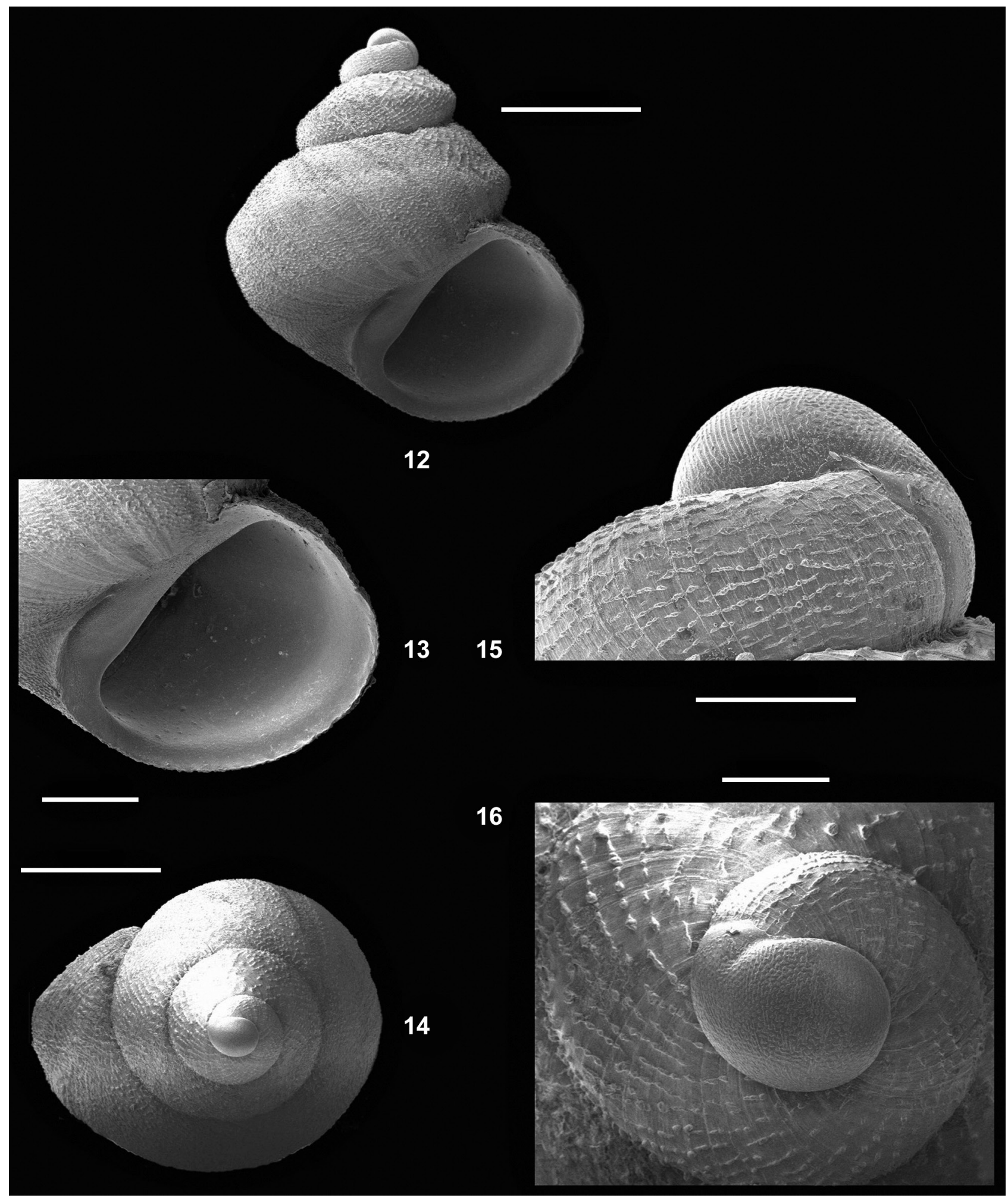

Figs 12-16. Georissa carinata Sutcharit et Jirapatrasilp, 2020: 12 - frontal view, 13 - detail of aperture, 14 - apical view, 15 - detail of apex, lateral view, 16 - detail of apex, apical view (SEM images: P. DuMRONGROJWATTANA). Scale bars $1 \mathrm{~mm}$ (Figs 12, 14), $0.5 \mathrm{~mm}$ (Fig. 13) and $0.2 \mathrm{~mm}$ (Figs 15-16) 
J. Vermeulen \& K. ANKeR, V7944/>10); Núi Bài Với, east flank, large doline approx. halfway along length of hill (leg. J. J. VermeULEN, V11240/>10); ditto, north part (Núi Mo So), Hospital Cave area (leg. J. J. VERMEULEN, V11274/>10); ditto, north part (Núi Mo So), Hospital Cave area, large doline (leg. L. Deharveng \& A. Bedos, V10019/>10); ditto, north part (Núi Mo So), northwest and east flanks (leg. TRUONG QUANG TAM; re-sampled by J. J. VERMEULEN \& K. ANKER, V9937/>10); ditto, southwest flank, rocky, locally steep limestone slope (leg. J. J. VermeUlen \& K. ANKER, V14992/>10); Núi Hang Tiền (leg. L. DEHARVENG \& A. BEDOS; re-sampled by J. J. VermeULEN, V10017/>10); Núi Khoe Lá, northern remnant, seaward side (leg. J. J. VERMEULEN \& LY NGỌC SAM; re-sampled by J. J. VERMEULEN \& K. ANKER, V14866/>10); ditto, small, most seaward limestone outcrop off the main hill (leg. J. J. VERMEULEN \& LY NGỌC SAM, V14890/>10); ditto, south remnant, landward side (leg. J. J. VERMEULEN \& K. ANKER, V14919/>10); Núi Nhỏ (leg. J. J. VERMEULEN \& LY NGOC SAM, V14765/>10); Núi Sơn Trà, limestone outcrop along north flank of sandstone hill (leg. J. J. VERMEULEN \& LY NGỌC SAM; re-sampled by J. J. VERMEULEN \& K. ANKER, V7955/>10); Hòn Chồng area: Núi Chùa Hang (= Pagoda Hill), north flank of hill and west end, slopes bordering temple complex (leg. J. J. VERMEULEN; re-sampled by J. J. VERMEULEN \& K. ANKER, V9994/>10); ditto, southeast end of hill, steep sea-facing slope (leg. J. J. VERMEULEN \& K. ANKER, V14967/>10).

Cross diagnosis. Within Georissa uniquely identified by the coarse, densely verrucose surface, with the verrucae arranged in partly concatenated rows perpendicular to the growth lines (and distinctly oblique to the suture) on the first whorls as well as on the body whorl below the suture, and arranged in similar rows in a more random pattern elsewhere on the body whorl. Other species of Georissa have either spiral sculpture, or radial sculpture, or both, or a very fine sculpture which is slightly oblique to the suture. Description. S h e 11 (Figs 10-12) very small, solid, opaque, orange, yellow or white. Surface dull. Spire (depressed-)conical, apex obtuse, body whorl somewhat turned inwards or not. Whorls convex, body whorl sometimes evenly rounded but usually more narrowly rounded at the periphery than elsewhere or obtusely angular, slightly rounded to slightly concave above and slightly rounded below.

\section{REFERENCES}

DUMRONGROJWATTANA P. 2008. A new species of Aulacospira (Pulmonata: Stylommatophora: Pupillidae) from Eastern Thailand. The Natural History Journal of Chulalongkorn University 8: 57-59.
S c u l p t u r e (Figs 13-16). Protoconch with rows of partly interconnected, flat verrucae in two directions perpendicular to each other (at $100 \times$ magnification). Teleoconch. Radial sculpture subordinate: unevenly spaced, locally somewhat raised growth lines; next to this, small, rather densely-placed, irregularly-shaped, high verrucae, arranged in partly concatenated rows roughly perpendicular to the growth lines on the first whorls as well as on the body below the suture, and elsewhere on the body whorl arranged in similar rows in a largely random pattern.

A p e r t u r e approximately semi-elliptic, parietal side approx. straight to slightly concave.

$\mathrm{U} \mathrm{m} \mathrm{b}$ i 1 i c u s (Fig. 13) closed, umbilical region a narrow, somewhat impressed slit bordered by a thin thread in some specimens, unmarked in others. D i m e $\mathrm{n} \mathrm{s}$ i o $\mathrm{n} \mathrm{s}$. Height 2.9-3.9 mm; width 2.1-3.0 mm; height/width 1.07-1.43; number of whorls up to $41 / 4$; aperture height $1.15-1.8 \mathrm{~mm}$; aperture width 1.4-1.9 mm.

Habitat. On algae- and lichen-covered limestone rock (Figs 8-9); the shells thickly covered with the same assemblage of organisms.

Distribution. Common and widespread in the Mekong Delta limestone hills. Presumably endemic to the area.

Note. The protologue is based on comparatively small shells, smaller than the abundant material seen by us. This also includes shells (Figs 10-11) which are distinctly narrower than the type. Yet, we cannot distinguish discrete forms, and the unique sculpture strongly suggests all material belongs to a single species. We provide an extensive description and detailed images of the sculpture on the protoconch and the first whorl of the teleoconch.

\section{ACKNOWLEDGEMENTS}

We wish to acknowledge the support of the Ministry of Environment of Cambodia and the Kiêng Giang provincial government of Vietnam. We also acknowledge organisations that funded the surveys, namely Chip Mong INSEE Cement Corporation (CMIC), and Siam City Cement (Vietnam) Limited (SCCVN, previously LafargeHolcim Vietnam, and Holcim Vietnam Ltd). Finally, we thank PONGRAT DUMRONGROJWATTANA for allowing us to use his excellent SEM images of Georissa carinata.

HidAlgo J. G. 1890-1891. Obrasmalacológicas. Parte I. Estudios preliminaries sobre la fauna malacológica de las Islas Filipinas. Memorias de la Real Academia 
de Ciencias Exactas, Físicas y Naturales de Madrid 14: $12-632$.

PÁll-Gergely B., SChilthuizen M., Örstan A. AufFENBERG K. 2019. A review of Aulacospira Möllendorff, 1890 and Pseudostreptaxis Möllendorff, 1890 in the Philippines (Gastropoda, Pupilloidea, Hypselostomatidae). ZooKeys 842: 67-83. https://doi. org/10.3897/zookeys.842.33052

PANHA S., BurCH J. B. 2002. The pupillid genus Aulacospira in Thailand (Pulmonata: Stylommatophora). Walkerana 12: 65-76.

PANHA S., TONGKerd P., Sutcharit C., BurCH J. B. 2004 New Pupillid species from Thailand (Pulmonata: Pupillidae). The Natural History Journal of Chulalongkorn University 4: 57-82.

SuTCHARIT C., THACH P., CHHUOY S., NGOR P. B., JERATTHITIKUl E., SiRIWUT W., SRISONCHAI R., NG T. H., PhOlYotha A., JirapatrasilP P., PANHA S. 2020. Annotated checklist of the land snail fauna from southern Cambodia (Mollusca, Gastropoda). ZooKeys 948: 1-46. https://doi.org/10.3897/zookeys.948.51671
Vermeulen J. J., Phung C. L., Truong Q. T. 2007. New species of terrestrial molluscs (Caenogastropoda, Pupinidae \& Pulmonata: Vertiginidae) of the Hon Chong - Ha Tien limestone hills, southern Vietnam. Basteria 71: 81-92.

Vermeulen J. J., LuU H. T., Keum T., AnKer K. 2019a. New species of land snails (Mollusca: Gastropoda: Caenogastropoda and Pulmonata) of the Mekong Delta Limestone Hills (Cambodia, Vietnam). Folia Malacologica 27: 7-41. https://doi.org/10.12657/folmal.027.001

Vermeulen J. J., LuU H. T., Keum T., Anker K. 2019 b. Land snail fauna of the Mekong Delta Limestone Hills: Notharinia Vermeulen, Phung et Truong, 2007, and a note on Plectostoma A. Adams, 1865 (Mollusca: Gastropoda: Caenogastropoda: Diplommatinidae). Folia Malacologica 27: 167-177. https://doi. org/10.12657/folmal.027.015

Received: June 7th, 2020

Revised: July 17th/28th, 2020

Accepted: August 15th, 2020

Published on-line: September 2nd, 2020 